\title{
The threat of the emergence of antimicrobial-resistant Gram-positive pathogens in Canada
}

DONALD E LOW MD, BARBARA M Willey art, Allison J MCGEer MD

\begin{abstract}
DE LOW, BM WILLEY, AJ MCGEER. The threat of the emergence of antimicrobial-resistant Gram-positive pathogens in Canada. Can J Infect Dis 1994;5(Suppl C):9C-14C. Since the early 1980s, much attention has been focused on the emergence of resistance in nosocomially acquired Gram-negative pathogens. However, in the 1990s we are witnessing in North America the development and spread of multiple resistance in Gram-positive pathogens in the hospital setting as well as in the community. Methicillinresistant Staphylococcus aureus and vancomycin-resistant enterococci are now endemic in many urban centres in the United States, although less so in Canada. In some states, penicillin-resistant Streptococcus pneumoniae in the community setting has gone from rates of less than 5\% in 1988 to $50 \%$ in 1994, including resistance to third-generation cephalosporins and carbapenems. Although these same pathogens have now been identified in Canada, we may still be in a position to limit or prevent their spread.
\end{abstract}

Key Words: Antimicrobial resistance, Gram-positive bacteria, Methicillin-resistant Staphylococcus aureus, Streptococcus pneumoniae

\section{Menace de nouveaux pathogènes Gram positifs résistants aux antimicrobiens au Canada}

RÉSUMÉ : Depuis le début des années 1980, l'émergence d'un phénomène de résistance manifesté par des pathogènes nosocomiaux Gram négatifs a fait passablement de bruit. Or, l'Amérique du Nord des années 1990 assiste au développement et à la propagation de pathogènes Gram positifs multi-résistants tant dans les établissements de santé que dans la communauté. Les Staphylococcus aureus méthicillinorésistants et les entérocoques résistants à la vancomycine sont désormais endémiques dans plusieurs centres urbains des États-Unis, et à un degré moindre, au Canada. Dans certains états, le taux de Streptococcus pneumoniae dans la communauté est passé de $5 \%$ en 1988 à $50 \%$ en 1994, y compris une résistance aux céphalosporines de troisième génération et aux carbapénèmes. Bien que ces mêmes pathogènes aient été identifiés au Canada, nous pourrions être en position de limiter ou de prévenir leur propagation.

The Mount Sinai and Princess Margaret Hospitals, University of Toronto, Toronto, Ontario

Correspondence and reprints: Dr DE Low, Department of Microbiology. Room 1487. Mount Sinai and Princess Margaret Hospitals, 600 University Avenue. Toronto, Ontario M5G 1X5. Telephone (416) 586-4435. Fax (416) 586-8746 
$\mathrm{T}$ HE INTRODUCTION OF PENICILLIN 50 YEARS AGO WAS FOL lowed rapidly by the identification of penicillinaseproducing staphylococci. After just 10 years of penicillin use, $73 \%$ of Staphylococcus aureus isolates from in-patients at the Boston City Hospital were penicillin-resistant (1). This is one of the earliest illustrations that one of the consequences of the introduction of any new antimicrobial agent is the development of bacterial resistance to its action $(2,3)$. Such resistance may arise by a mutation that reduces target affinity or allows the overproduction of a drug modifying enzyme. However, the introduction into a bacterium of foreign DNA encoding for resistance may bypass the need for endogenous mutational events. This DNA may be introduced into the chromosome by transformation and recombination or may be integrated into the bacterial cell on plasmids, which may be transferable from one organism to another by conjugation, transduction or transformation $(4,5)$. In this article we review the emergence of methicillin-resistant $S$ aureus (MRSA), multiply resistant Enterococcus species and penicillin-resistant Streptococcus pneumoniae (PRSP), and discuss the threat they may pose in Canada.

\section{METHICILLIN-RESISTANT STAPHYLOCOCCUS AUREUS}

Soon after methicillin became available, resistance to it was reported in $S$ aureus. This resistance was not the result of destruction of the antibiotic by a betalactamase (6). It was subsequently found that the resistant strains had a newly acquired resistance gene, mecA, that encoded for a penicillin binding protein (PBP), PBP-2a (7,8). PBP-2a is able to maintain cell wall integrity during growth and division when native enzymes (PBPS) needed for assembly of the cell wall are inactivated by beta-lactam antibiotics. The spread of staphylococcal clones carrying the mecA gene has resulted in the worldwide dissemination of MRSA (9). Outbreaks reported in the United States in the 1970s were confined primarily to large, tertiary care teaching hospitals $(10,11)$. However, in the 1980 s some community hospitals and rehabilitation and extended care facilities experienced an increasing prevalence of MRSA colonization and/or infection (11-13). For instance, the prevalence of MRSA increased dramatically in Veterans Administration medical centres between 1975 and 1984 (14). MRSA continues to be endemic in many of these facilities.

In Canada, the prevalence of MRSA remains low relative to other countries, but varies in different provinces, cities and hospitals. A point prevalence survey to determine MRSA colonization rates at three university-affiliated tertiary care facilities in downtown Toronto found that none of 1219 patients were colonized with MRSA (personal communication). McArthur et al (15) surveyed $20 \%$ of residents in each of 132 long term care facilities in Ontario for colonization with MRSA. One or more MRSA colonized residents were identified in eight of 132 facili- ties $(6.1 \%, 95 \%$ confidence level 1.9 to $10.2 \%)$. Only two facilities had previously recognized the presence of MRSA. Taylor et al (16) at the University of Alberta Hospitals found that the majority of MRSA isolates from hospitalized patients was community acquired and that most were isolated from residents of one aboriginal community. A study done by Embil et al (17) reviewed the experience with five tertiary care teaching hospitals on the Canadian prairies, and found similar results. Patients usually had MRSA identified at admission: in only one of five centres was the majority of isolates acquired nosocomially. Patients with MRSA present at admission were more frequently aboriginal. It appears that in Canada the major reservoirs for MRSA may be outside the hospital setting.

Can MRSA be controlled once introduced into a hospital? Boyce (18) reviewed 46 published outbreaks and found that early implementation of control measures was associated with success in eradication. All 11 hospitals with 20 or fewer cases were successful in eradicating MRSA compared with only $71 \%$ with 20 to 39 cases and $10 \%$ with 40 or more cases. In Sarnia, Ontario 21 patients with MRSA were identified in a secondary care hospital between March 1990 and January 1991 (19). The reservoir was suspected to be in nursing homes in the community. A survey of all hospital patients and nursing home residents in Sarnia was carried out, and those found to be colonized with MRSA were treated. All subsequent admissions from other institutions were screened for MRSA and treated if colonized. Since the institution of these policies no further outbreaks have occurred as of January 1994 (personal communication). Policies requiring admission screening of patients at risk for MRSA colonization (eg, admitted from an area where MRSA is endemic) may control the spread of this organism in Canada.

\section{MULTIPLY RESISTANT ENTEROCOCCUS SPECIES}

The enterococcus is an important nosocomial pathogen despite its low virulence: in National Nosocomial Infections Surveillance System (NNIS) hospitals, enterococci are the third most common pathogen associated with nosocomial bloodstream infections and the second most commonly isolated nosocomial pathogen overall (20-23). This is due to the organism's ubiquitous nature, its inherent antimicrobial resistance, and its ability to acquire multiple resistance traits.

Acquired high-level resistance to the aminoglycosides was first reported in the 1970s. By the mid1980s many reports had documented high-level aminoglycoside resistance in both Enterococcus faecalis and Enterococcus faecium (24-26). Resistance to betalactams has also dramatically increased during the past decade (27-30). This resistance is usually a result of an increase in the amount of low affinity PBPs synthesized by the cell (31). However, high-level ampicillin resistance may also occur due to the acquisition of 
a beta-lactamase gene $(32,33)$. High-level vancomycin resistant strains were first detected in 1986. Since then they have spread at an alarming rate (34-37). Outbreaks have been reported both in teaching and community hospital settings (36-41). In NNIS hospital intensive care units, the prevalence of vancomycin resistant enterococci (VRE) has increased from less than $1 \%$ to more than $10 \%$ in the three years from 1990 to 1992 (42). In New York City, the first isolate of VRE was identified in September 1989. Reports of VRE then increased almost exponentially, with 38 hospitals reporting 361 isolates by October 1991 (36).

Studies of the genetics and mechanisms of glycopeptide resistance in enterococci have suggested three classes of resistance: A, B and C. All classes have genes that encode for a cell wall precursor with a reduced affinity for glycopeptide antibiotics (43). Isolates with resistance to high levels of vancomycin (mimimum inhibitory concentration [MIC] $256 \mu \mathrm{g} / \mathrm{mL}$ or greater) and to teicoplanin (MIC $16 \mu \mathrm{g} / \mathrm{mL}$ or greater) have been classified as phenotypic class A. This is the most prevalent phenotype. It is encoded for by the vanA gene, which may be transferred between strains on plasmids and transposons. Class B strains are resistant to vancomycin, with MICs ranging from 16 to $1024 \mu \mathrm{g} / \mathrm{mL}$, but are susceptible to teicoplanin (MIC less than $8.0 \mu \mathrm{g} / \mathrm{mL}$ ). This type of resistance is encoded for by the vanB gene, which is also transferable. Class $\mathrm{C}$ resistance, found in Enterococcus gallinarium and Enterococcus casseliflavus, comprises constitutive low-level resistance to vancomycin (MIC $4.0 \mu \mathrm{g} / \mathrm{mL}$ or greater, or $32 \mu \mathrm{g} / \mathrm{mL}$ or less) and susceptibility to teicoplanin (43-45). This type of resistance is chromosomal, intrinsic and nontransferable. The study of the rapid spread of glycopeptideresistant enterococci in Europe and the United States suggests that dissemination occurs not only by clonal spread of individual strains, but also by the horizontal spread of resistance determinants from strain to strain $(36,40,46)$. The rapid worldwide emergence of vancomycin resistance in enterococci more than 35 years after the introduction of this antibiotic probably reflects selective pressure due to its increased use $(47,48)$. For instance, Ena et al (48) found that the rate of vancomycin use at a university hospital increased from $5.7 \mathrm{~g} / 1000$ patient days in 1981 to $21 \mathrm{~g} / 1000$ patient days in 1991 .

In Canada, both high-level aminoglycoside-resistant and beta-lactamase-negative ampicillin resistant enterococci have been reported $(49,50)$. There has been only one case report of a beta-lactamase-producing $E$ faecalis isolate (51). The first vancomycin-resistant isolate of $E$ faecium was described by Kibsey et al (52). This organism was isolated from two patients in an intensive care unit. Both patients were immunocompromised and had received broad spectrum antimicrobial therapy.

The emergence and dissemination of multiply resistant enterococci is resulting in infections for which there are no uniformly effective therapeutic options.
The possibility that the vanA gene will transfer into other Gram-positive organisms such as MRSA and/or PRSP is of even greater concern. The transfer of vancomycin resistance from enterococci to $S$ aureus has already been accomplished in vivo in the laboratory (53). VRE are readily detectable in the laboratory if appropriate antimicrobial testing practices are employed $(54,55)$. Once identified, control of the spread of this organism will require strict adherence to infection control practices and the institution of a surveillance program to identify colonized patients and health care workers. Otherwise what has happened in the United States, and in particular in New York City, could easily occur in Canada (36).

\section{PENICILLIN-RESISTANT STREPTOCOCCUS PNEUMONIAE}

Of equal concern is the rapid emergence of PRSP in North America. In 1967, the first patient infected with a PRSP strain with intermediate resistance to penicillin (MIC 0.1 to $1.0 \mu \mathrm{g} / \mathrm{mL}$ ) was reported from Australia (56). Subsequently, other strains were identified in New Guinea and Australia (57,58). In 1977 in South Africa, outbreaks of the first strains that were highly penicillin-resistant (MIC $2 \mu \mathrm{g} / \mathrm{mL}$ or greater) were reported (59), as was the first multiply resistant strain (resistant to penicillin, tetracycline, erythromycin, clindamycin, trimethoprim-sulphamethoxazole and chloramphenicol) $(59,60)$. PRSP infection in the United States was initially reported in 1974 (61), and the first resistant Canadian isolates were described in the mid-1970s (62). Before 1987, in the United States only 5\% of pneumococci demonstrated intermediate resistance and less than 1\% were highly resistant (63). The last two Canadian surveillance studies, performed in the 1980 s, found less than $1.5 \%$ of isolates to have intermediate resistance and none to be highly resistant $(64,65)$. Recently, however, disturbingly high rates of PRSP (more than 50\%) have been identified in Spain and Hungary $(66,67)$, and several reports from the United States document increases in the number of PRSP. From 1987 to 1992 , the proportion of $S$ pneumoniae strains submitted to the Centers for Disease Control and Prevention that were highly resistant to penicillin increased from $0.02 \%$ to $1.3 \%$ (68). In community surveys in Kentucky and Tennessee in 1993 it was found that $65 \%$ and $39 \%$, respectively, of $S$ pneumoniae strains were PRSP, and of these $65 \%$ and $30 \%$, respectively, were highly resistant to penicillin (69).

Resistance to penicillin in clinical isolates of $\mathrm{S}$ pneumoniae is due to the development of PBPs that have greatly decreased affinity for the antibiotic (70-72). In those isolates that have the highest levels of resistance to penicillin, there have been reductions in the affinity of at least four of the five high molecular weight PBPS (73). Low affinity forms are believed to have arisen by localized interspecies recombinational events that re- 
place parts of the PBP gene with the corresponding parts of the homologous genes of closely related species (74). That is, the $S$ pneumoniae has acquired PBP genes from other streptococci that are resistant to penicillin. Thus, the evolution of resistance in S pneumoniae is somewhat different from that in MRSA or enterococci. The mecA and vanA genes are highly conserved, and their spread occurs either by clonal dissemination of a strain carrying them (as usually occurs with MRSA), or by their transfer from strain to strain on a plasmid or transposon (as occurred with enterococci in New York City) $(75,76)$. Although clonal dissemination of strains of PRSP has occurred (77), the transformation and recombination events that transfer penicillin resistance to $S$ pneumoniae are not uncommon, and the emergence of PRSP may be due to the repeated new development of low affinity PBPS (78).

In Canada there has been a recent increase in reports of PRSP. In an unselected sample of 2642 isolates of S pneumoniae collected from across Canada, 252 $(9.5 \%)$ were found to be resistant to penicillin by the oxacillin screen test. Of the resistant isolates, 39 were from blood cultures, four from sterile fluids and 209 from the respiratory tract. One hundred and twentyseven of these were from Ontario, 31 from British Columbia, 34 from Alberta, 27 from Saskatchewan, 13 from Manitoba, 10 from Quebec, eight from the Maritimes and two from Yukon. Of the 146 isolates available for antimicrobial susceptibility testing, 37 exhibited high level resistance (penicillin MIC at least $2.0 \mu \mathrm{g} / \mathrm{mL}$ ) and 109 had intermediate levels of resistance (penicillin MIC 0.12 to $1.0 \mu \mathrm{g} / \mathrm{mL}$ ). Among the 99 isolates serotyped, 17 different serotypes were represented. The four predominant serotypes were: $23 \mathrm{~F}(10), 9 \mathrm{~A}(10), 9 \mathrm{~V}$

\section{REFERENCES}

1. Finland M. Changes in the susceptibility of selected pathogenic bacteria to widely used antibiotics. Ann N Y Acad Sci 1971;182:5-20.

2. Fluit AC, Visser MR. Nucleic acid analysis of antibiotic resistance. Int J Antimicrob Agents 1992;1:205-22.

3. Cohen ML. Epidemiology of drug resistance: Implications for a post-antibiotic era. Science 1992;257:1050-5.

4. Jacoby GA. Swartz MN. Plasmids: Microbiologic and clinical importance. Semin Infect Dis 1980:3:1-37.

5. Jacoby GA, Archer GL. New mechanisms of bacterial resistance to antimicrobial agents. $\mathrm{N}$ Engl $\mathrm{J}$ Med 1991;324:601-12.

6. Seligman SJ. Penicillinase-negative variants of methicillin-resistant Staphylococcus aureus. Nature 1966;209:994-6.

7. Hartman BJ, Tomasz A. Expression of methicillin resistance in heterogenous strains of Staphylococcus aureus. Antimicrob Agents Chemother 1986;29:85-92.

8. Utsui Y, Yokota T. Role of an altered penicillin-binding protein in methicillin- and cephem-resistant

Staphylococcus aureus. Antimicrob Agents Chemother 1985:28:397-403.

9. Maple PAC, Hamilton-Miller JMT, Brumfitt W. World-wide antibiotic resistance in methicillin-resistant Staphylococcus aureus. Lancet 1989;i:537-40. (seven) and 6B (six) (personal communication).

The appearance of PRSP in Canada has several important implications. First, if rates of resistance in a community become greater than 3\%, then first-line low-cost antimicrobials for empirical therapy (ie, penicillin) may have to be replaced with more costly agents. Second, beta-lactams other than penicillin have reduced activity against PRSP isolates, thereby potentially limiting the use of a whole class of antimicrobials $(79,80)$. Finally, alternative antimicrobials to penicillin for the treatment of invasive infections due to high-level resistant S pneumoniae are not as effective as penicillin for penicillinsusceptible strains, so that therapy for patients with these infections may be compromised $(81,82)$. Effective alternative antimicrobials for invasive disease due to PRSP in nonmeningitis cases are ceftriaxone and cefotaxime.

\section{CONCLUSIONS}

There are several strategies to try to combat the problem of emerging antimicrobial resistance. One approach is to reduce selective pressure for the development of resistance by more prudent use of antimicrobials. Equally important is the need for better surveillance to determine the frequency of antimicrobial resistance so that studies can be designed to determine the important factors in the emergence, persistence and transmission of drug-resistant organisms. Ongoing transmission of organisms being introduced may then be controlled. As Cohen (3) noted, "unless currently effective antimicrobial agents can be successfully preserved and the transmission of drug-resistant organisms curtailed, the post-antimicrobial era may be rapidly approaching".

10. Chambers HF. Methicillin-resistant staphylococci. Clin Microbiol Rev 1988;1:173-86.

11. Jorgensen JH. Laboratory and epidemiology experience with methicillin-resistant Staphylococcus aureus in the USA. Eur J Clin Microbiol 1986;5:693-6.

12. Klimek JJ, Marsik FJ, Bartlett RC, Weir B, Shea P, Quintiliani R. Clinical, epidemiologic and bacteriologic observations of an outbreak of methicillin-resistant Staphylococcus aureus at a large community hospital. Am J Med 1976;61:340-5.

13. Aeilts GD, Sapico FL, Canowati HN, Malik GM, Montgomerie JZ. Methicillin-resistant Staphylococcus aureus colonization and infection in a rehabilitation facility. J Clin Microbiol 1982; 16:219-23.

14. Preheim LC, Rimland D, Bittner MJ. Methicillin-resistant Staphylococcus aureus in veterans' administration medical centers. Infect Control 1987;8:191-4,

15. McArthur M, O'Quinn K, Jaeger R, Low DE, Simor AE, McGeer A. Prevalence of methicillin-resistant Staphylococcus aureus in Ontario long term care facilities. Am J Infect Control 1993;21:100. (Abst)

16. Taylor G, Kirkland T, Kowalewska-Grochowska K, Wang Y. A multistrain cluster of methicillin-resistant Staphylococcus aureus based in a native community. Can J Infect Dis 1990;1:121-6.

17. Embil J, Nicolle LE, Conly J, et al. Methicillin-resistant 
Staphylococcus aureus (MRSA): The Canadian Prairie experience 1990-1992. The 1993 Annual Meeting of The Royal College of Physicians and Surgeons of Canada. Vancouver, BC. Clin Invest Med 1993:16(Suppl B):1379. (Abstract 49)

18. Boyce JM. Should we vigorously try to contain and control methicillin-resistant Staphylococcus aureus? Infect Control Hosp Epidemiol 1991; 12:46-54.

19. Boyd N, Gidwani R, Englehart CE. Colonization of methicillin-resistant Staphylococcus aureus in Southwestern Ontario. Can Dis Wkly Rep 1991;17:72-3.

20. Moellering RC Jr. Emergence of enterococcus: A significant pathogen. Clin Infect Dis 1992;14:1173-8.

21. Spera RV, Farber BF. Multiply-resistant Enterococcus faecium. The nosocomial pathogen of the 1990's. JAMA 1992:268:2563-4.

22. Steady increase in resistant enterococcus poses new threat. Hosp Infect Control 1993:20:1-5. (Edit)

23. Schaberg DR, Culver DH, Gaynes RP. Major trends in the microbial etiology of nosocomial infections. Am J Med 1991:91:72S-5S.

24. Moellering RC, Wennersten C, Medrek T, Weinberg AN. Prevalence of high-level resistance to aminoglycosides in clinical isolates of enterococci. Antimicrob Agents Chemother 1970;1:335-40.

25. Mederski-Saworaj BD, Murray BE. High-level resistance to gentamicin in clinical isolates of enterococci. J Infect Dis $1983 ; 147: 751-7$.

26. Murray BE, Tsao J, Pomida J. Enterococci in Bangkok, Thailand, with high-level resistance to currently available aminoglycosides. Antimicrob Agents Chemother 1983:23:799-802.

27. Boyce JM, Opal SM, Potter-Bynoe G, et al. Emergence and nosocomial transmission of ampicillin-resistant enterococci. Antimicrob Agents Chemother 1992:36: 1032-9.

28. Bush LM, Calmon J, Cherney CL, et al. High-level penicillin resistance among isolates of enterococci: Implications for treatment of enterococcal infections. Ann Intern Med 1989;110:515-20.

29. Grayson MI, Eliopoulos GM, Wennersten CB, et al. Increasing resistance to $\beta$-lactam antibiotics among clinical isolates of Enterococcus faecium: A 22-year review at one institution. Antimicrob Agents Chemother 1991;35:2180-4.

30. Sapico FL, Canawati HN, Ginunas VJ, et al. Enterococci highly resistant to penicillin and ampicillin. An emerging clinical problem? J Clin Microbiol 1989;27:2091-5.

31. Fantena R, Amalfitaro G, Rossi L, Solta G. Mechanism of resistance to growth inhibition and killing by $\beta$-lactam antibiotics in enterococci. Clin Infect Dis 1992;15:486-9.

32. Murray BE, Singh KU, Markowitz SM, et al. Evidence for clonal spread of a single strain of $\beta$-lactamase producing Enterococcus (Streptococcus) faecalis to six hospitals in five states. J Infect Dis 1971;163:780-5.

33. Murray BE. $\beta$-lactamase producing enterococci. Antimicrob Agents Chemother 1992;36:2355-9.

34. Leclereq R, Derlot E, Duval J, Courvalin P. Plasmid-mediated resistance to vancomycin and teicoplanin in Enterococcus faecium. N Engl J Med 1988;319:157-61

35. Uttley AHC, George RC, Naidoo J, et al. High-level vancomycin-resistant enterococci causing hospital infection. Epidemiol Infect 1989;103:173-81.

36. Freiden TR. Munsiff SS, Low DE, et al. Emergence of vancomycin-resistant enterococci in New York City. Lancet 1993:342:76-9.

37. Jones RN, Erwin ME, Enterococcus Study Group.
Emerging multiply resistant enterococci among clinical isolates. Program and Abstracts of the 33rd Interscience Conference on Antimicrobial Agents and Chemother (abst 1052). Washington: American Society of Microbiology, 1993.

38. Rubin LG, Tucci V, Cercenado E, Eliopoulos G, Isenberg HD. Vancomycin-resistant Enterococcus faecium in hospitalized children. Infect Control Hosp Epidemiol 1992; 13:700-5.

39. Karanfil LV, Murphy M. Josephson A, et al. A cluster of vancomycin-resistant Enterococcus faecium in an intensive care unit. Infect Control Hosp Epidemiol 1992: 13:195-200.

40. Clark NC, Cocksey RC, Hill BC, Swenson JM, Tenover FC. Characterization of glycopeptide-resistant enterococci from US hospitals. Antimicrob Agents Chemother 1993:37:2311-7.

41. Livornese LL, Dias S, Samel C, et al. Hospital-acquired infection with vancomycin-resistant Enterococcus faecium transmitted by electronic thermometers. Ann Intern Med 1992;117:112-6.

42. Centers for Disease Control and Prevention. Nosocomial enterococci resistant to vancomycin-United States, 1989-1993. MMWR 1993:42:597-9.

43. Arthur M. Courvalin P. Genetics and mechanisms of glycopeptide resistance in enterococci. Antimicrob Agents Chemother 1993;37:1563-71.

44. Gold HS, Unal S, Cercenado E, et al. A gene confirming resistance to vancomycin but not teicoplanin in isolates of Enterococcus faecalis and Enterococcus faecium demonstrates homology with $\operatorname{van} \mathrm{B}$, van $\mathrm{A}$, and $\operatorname{van} \mathrm{C}$ genes of enterococci. Antimicrob Agents Chemother 1993;37:1604-9.

45. Quintilani R Jr, Evans S, Courvalin P. The vanB gene confers various levels of self-transferable resistance to vancomycin in enterococci. J Infect Dis 1993;167:1220-3.

46. Dutka-Malen S, Molinas C, Arthur M, Courvalin P. The VAN A glycopeptide resistance protein is related to D-analyl-D-alamine ligase cell wall biosynthesis enzymes. Mol Gen Genet 1990:224:364-72.

47. Pallares R, Dick R, Wenzel RP, Adams JR, Nettleman MD. Trends in antimicrobial utilization at a tertiary teaching hospital during a 15-year period (1978-1992). Infect Control Hosp Epidemiol 1991;12:525-34.

48. Ena J, Dick RW, Jones RN, Wenzel RP. The epidemiology of intravenous vancomycin usage in a university hospital. JAMA 1993;269:598-602.

49. Forward KR, Kennedy JK, DeGagne PA, Bartlett KR, Harding GKM. The rapid emergence of high level gentamicin resistance in enterococci. Can J Infect Dis 1990; 1:97-100.

50. Eymard D, Dascal A, Hiscott J, et al. Non-betalactamase-producing penicillin-resistant Enterococcus faecium in a clinical setting. Can J Infect Dis 1990;1:73-6.

51. Mazzulli T, King SM, Richardson SE. Bacteraemia due to $\beta$-lactamase-producing Enterococcus faecalis with high-level resistance to gentamicin in a child with Wiskott-Aldrich Syndrome. Clin Infect Dis 1992;14:780-1.

52. Kibsey PC, Willey B, Low DE, Cain D, Boychuc LR, Heule M. Vancomycin multi-resistant Enterococcus faecium: First Canadian isolate (Abst no K5). In: Program and abstracts of the 61st Conjoint Meeting of Infectious Diseases. Vancouver: Canadian Association for Clinical Microbiology and Infectious Diseases, 1993.

53. Noble WC, Virani Z, Cree RGA. Co-transfer of vancomycin and other resistance genes from Enterococcus faecalis NCTC 12201 to Staphylococcus aureus. FEMS Microbiol Lett 1992;93:195-8.

54. Willey B, Kreiswirth BN, Simor AE, et al. Detection of 
vancomycin resistance in Enterococcus species. J Clin Microbiol 1992:30:1621-4.

55. Willey B, Kreiswirth, Simor AE, et al. Identification and characterization of multiple species of vancomycin-resistant enterococci, including an evaluation of Vitek software version 7.1. J Clin Microbiol 1993:31:2777-9.

56. Hansman D, Bullen MM. A resistant pneumococcus. Lancet 1967;ii:264-5. (Lett)

57. Hansman D, Glasgow H, Sturt J, Devitt HL, Douglas R. Increased resistance to penicillin of pneumococci isolated from man. N Engl J Med 1971;284: 175-7.

58. Hansman D, Devitt L, Miles H. Riley I. Pneumococci relatively insensitive to penicillin in Australia and New Guinea. Med J Aust 1974;2:353-6.

59. Appelbaum PC, Bhanjee A, Scragg JN, Hallett AF. Bowen AJ, Cooper RC. Streptococcus pneumoniae resistant to penicillin and chloramphenicol. Lancet 1977;ii:995-7.

60. Jacobs MR, Koornhof HJ, Robins-Browne RM, et al. Emergence of multiply resistant pneumococci. N Engl J Med 1978:229:735-40.

61. Naraqi S, Kirkpatrick GP. Kabis S. Relapsing pneumococcal meningitis: isolation of an organism with decreased susceptibility to penicillin G. J Pediatr 1974:85:671-3.

62. Dixon JMS, Lipinski AE, Graham MEP. Detection and prevalence of pneumococci with increased resistance to penicillin. Can Med Assoc J 1977; 117:1 159-61.

63. Spika JS, Facklam RR, Plikaytis BD, Oxtoby MJ, Pneumococcal Surveillance Working Group. Antimicrobial resistance of Streptococcus pneumoniae in the United States. J Infect Dis 1991;163:1273-8.

64. Jette LP, Lamothe F, Pneumococcus Study Group. Surveillance of invasive Streptococcus pneumoniae infection in Quebec, Canada from 1984 to 1986: serotype distribution, antimicrobial susceptibility and clinical characteristics. J Clin Microbiol 1989;27:1-5.

65. Mazzulli T, Simor AE, Jaeger R, Fuller S, Low DE. Comparative in vitro activities of several new fluoroquinolones and beta-lactam antimicrobials against community isolates of Streptococcus pneumoniae. Antimicrob Agents Chemother 1990:34:467-9.

66. Otis CL, Monoz TJ. Sala IS. Antibiotic susceptibility of Streptococcus pneumoniae isolates from paediatric patients. J Antimicrob Chemother 1988;22:659-65.

67. Marton A, Gulyas M, Munoz R, Tomasz A. Extremely high incidence of antibiotic resistance in clinical isolates of Streptococcus pneumoniae in Hungary. J Infect Dis 1991;163:542-8.

68. Bulter JC, Breiman RF, Facklam RR. Pneumococcal Working Group. Emergence of drug-resistant pneumococci in the United States (Abstract 1182). In: Program and abstracts of the 33rd Interscience Conference on Antimicrobial Agents and Chemotherapy. Washington DC: American Society of Microbiology,
1993:336.

69. Centers for Disease Control and Prevention. Drug-resistant Streptococcus pneumoniae - Kentucky and Tennessee, 1993. MMWR 1994;43:23-31.

70. Hakenbeck R, Tarpay M, Tomasz A. Multiple changes of penicillin-binding proteins in penicillin-resistant clinical isolates of Streptococcus penumoniae. Antimicrob Agents Chemother 1980;17:364-71.

71. Percheson PB, Bryan LE. Penicillin-binding components of penicillin-susceptible and -resistant strains of Streptococcus penumonaie. Antimicrob Agents Chemother 1980;12:390-6.

72. Zighelboim S, Tomasz A. Penicillin-binding proteins of multiply antibiotic-resistant South African strains of Streptococcus pneumoniae. Antimicrob Agents Chemother 1980; 17:434-42.

73. Hakenbeck R, Ellerbrok H, Briese T, Handwerger S, Tomasz A. Penicillin-binding proteins of penicillin-susceptible and -resistant pneumococci: immunological relatedness of altered proteins and changes in peptides carrying the $\beta$-lactam binding site. Antimicrob Agents Chemother 1986;30:553-8.

74. Maynard Smith JM, Dowson CG, Spratt BG. Localized sex in bacteria. Nature 1991;349:29-31.

75. Kreiswirth B, Kornblum J, Arbeit RD, et al. Evidence for a clonal origin of methicillin resistance in Staphylococcus aureus. Science 1993;259:227-30.

76. Arthur M, Molinas C, Depardieu F, Courvalin P. Characterization of Tn1546, a Tn3-related transposon conferring glycopeptide resistance by synthesis of depsipeptide peptidoglycan precursors in Enterococcus faecium BM4147. J Bacteriol 1993;175:117-27.

77. Jabes D, Nachman S, Tomasz A. Penicillin-binding protein families: evidence for the clonal nature of penicillin resistance in clinical isolates of pneumococci. $\mathrm{J}$ Infect Dis 1989;159:16-25.

78. McDougal LK, Facklam R, Reeves M, et al. Analysis of multiply antimicrobial-resistant isolates of Streptococcus pneumoniae from the United States. Antimicrob Agents Chemother 1992;36:2176-84.

79. Figueredo AMS, Connor JD, Severin A, Pato MVP, Tomasz A. A pneumococcal clinical isolate with high-level resistance to cefotaxime and ceftriaxone. Antimicrob Agents Chemother 1992;36:886-9.

80. Sloas MM, Barrett FF, Chesney PJ, et al. Cephalosporin treatment failure in penicillin- and cephalosporin-resistant Streptococcus pneumoniae meningitis. Pediatr Infect Dis J 1992;1 1:662-6.

81. Friedland IR, Klugman KP. Recurrent penicillin-resistant pneumococcal meningitis after chloramphenicol therapy. Pediatr Infect Dis J 1991; 10:705-7.

82. Viladrich PF, Gudiol F, Linares J, et al. Evaluation of vancomycin for therapy of adult pneumococcal meningitis. Antimicrob Agents Chemother 1991;35:2467-72. 


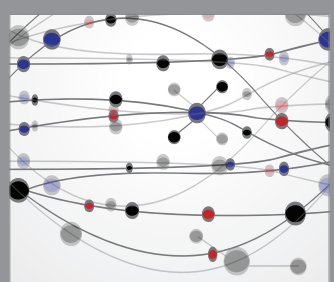

The Scientific World Journal
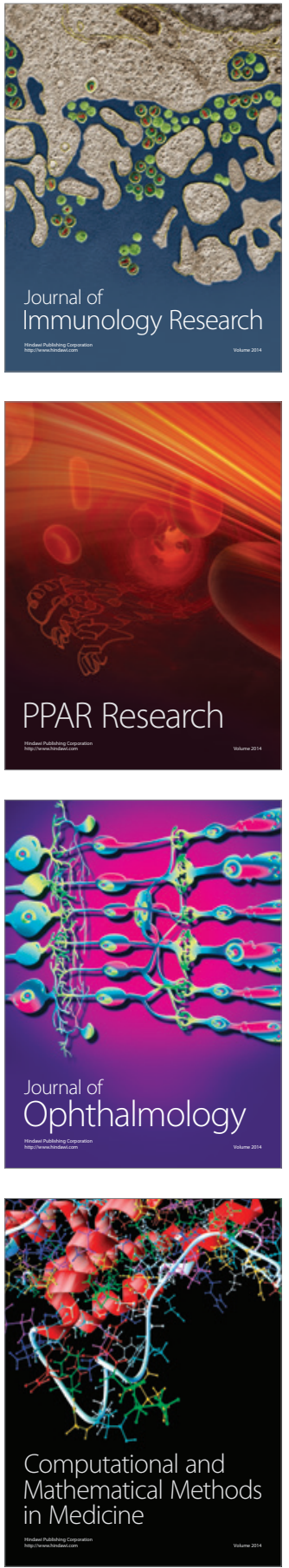

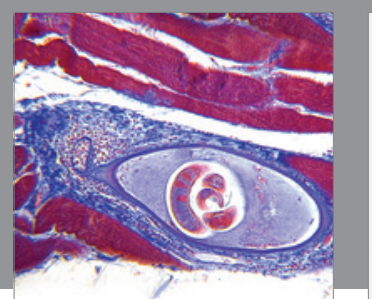

Gastroenterology Research and Practice

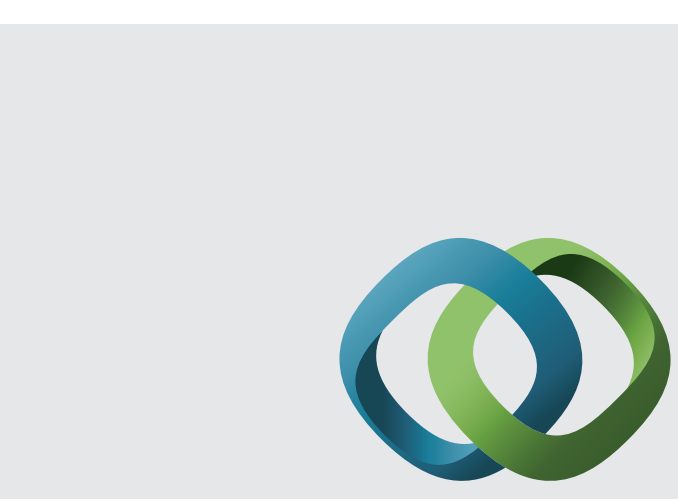

\section{Hindawi}

Submit your manuscripts at

http://www.hindawi.com
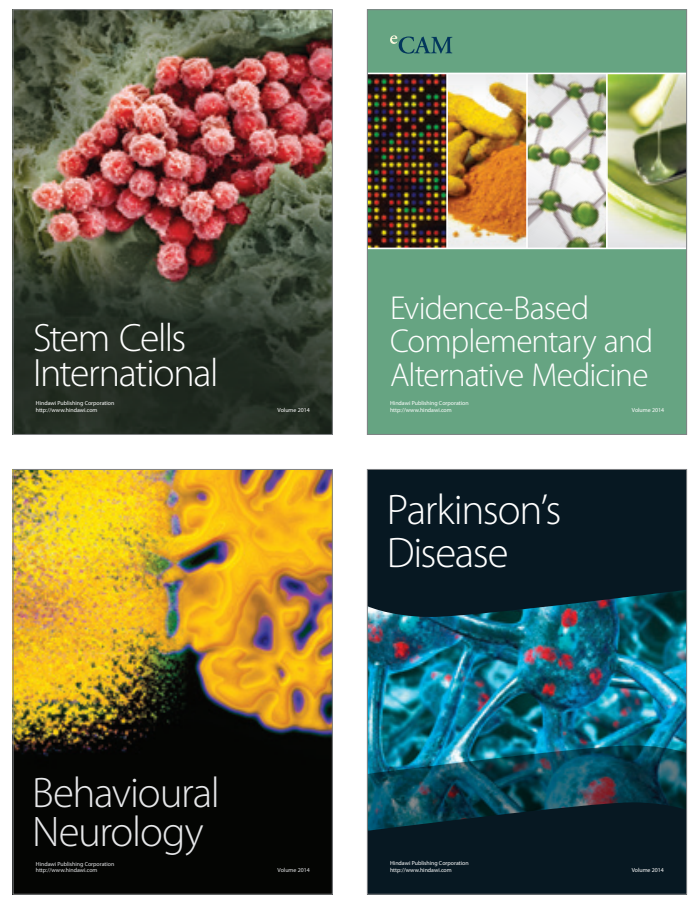
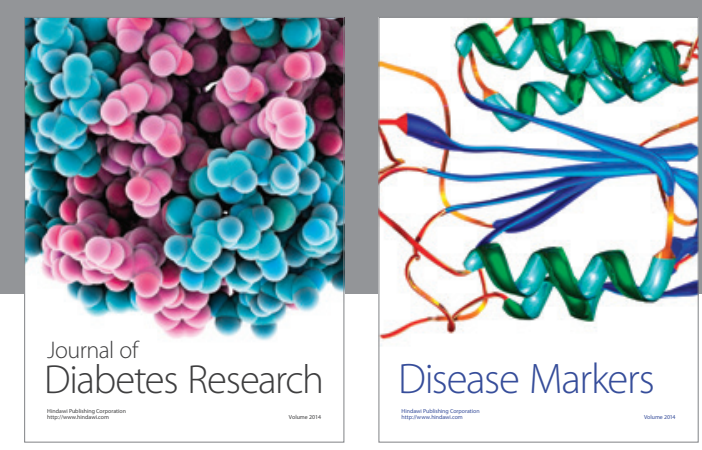

Disease Markers
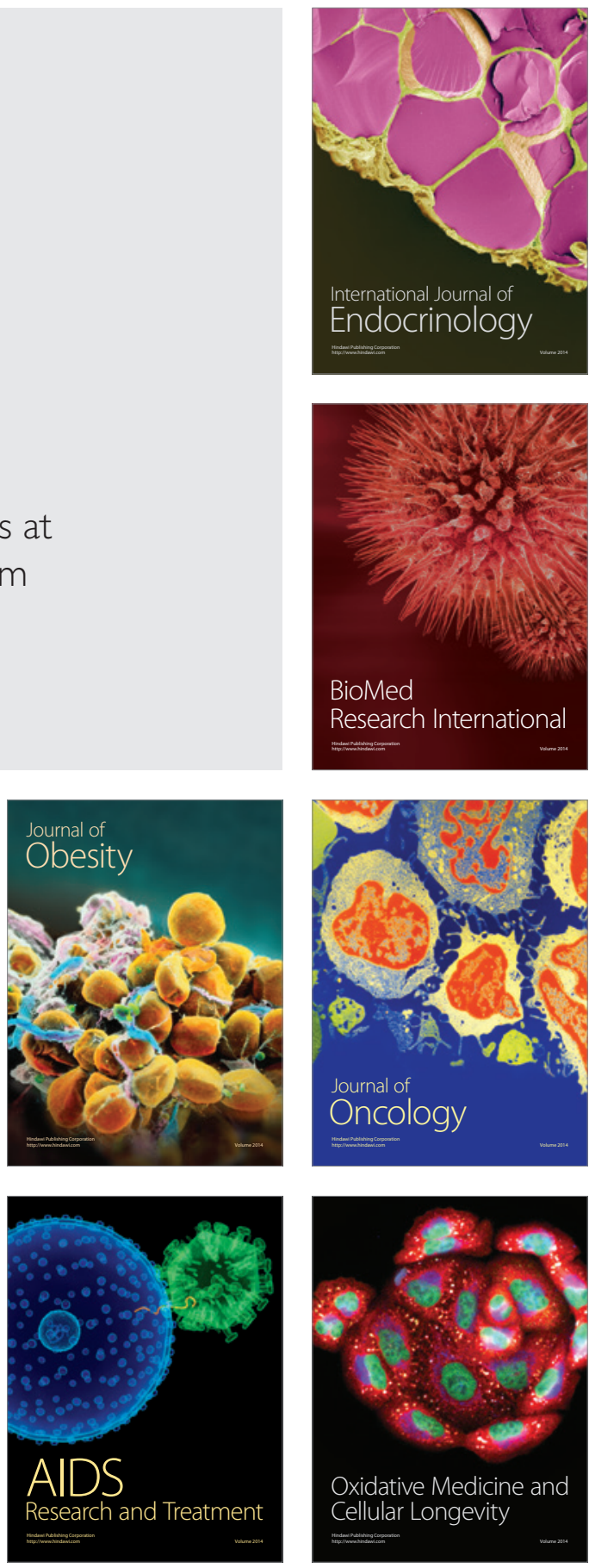